\title{
DA INDISSOCIABILIDADE ENTRE LITERATURA E SOCIEDADE A PARTIR DE "PATRIOTISMO" (1961) DE MISHIMA YUKIO ${ }^{1}$ THE INDISSOCIABILITY BETWEEN LITERATURE AND SOCIETY IN "PATRIOTISM" (1961) BY MISHIMA YUKIO
}

\author{
Rafael Felipe dos Santos ${ }^{2}$ \\ Alfeu Sparemberger ${ }^{3}$
}

\begin{abstract}
Resumo: A partir da reflexão sobre um dos mais célebres contos do escritor Mishima Yukio, conhecido por recorrer ao tópico do suicídio inúmeras vezes, pretende-se mostrar que a autoimolação reveste-se, seja em "Patriotismo" (1961) e repetidas vezes em outras obras de sua autoria, de uma forte referência cultural. Diferentemente da visão atribuída no ocidente de que a rigidez da sociedade nipônica e suas convenções são as responsáveis por fragilizar mentalmente os indivíduos a ponto de eles cometerem suicídio, parte-se do preceito de que é absolutamente necessário ampliar as categorias de entendimento na percepção de uma cultura fundada em ideais ainda mal elucidados aos que nela não estão inseridos. Acredita-se que talvez a literatura seja o caminho para tal esclarecimento, uma vez que ela não pode ser isolada da cultura da qual provém.
\end{abstract}

Palavas-chave: Mishima Yukio; Patriotismo; suicídio; literatura japonesa; estudos culturais.

Abstract: Based on the reflection about one of the most renowned short stories written by Mishima Yukio, known by constant suicide references, it is attempted to show that selfimmolation is recovered in "Patriotism" (1961), and several times in others Mishima's literary

1 Artigo submetido em 25/09/2017 e aprovado em 22/09/2018.

2 Graduando do curso de Letras - Português e Francês do Centro de Letras e Comunicação da Universidade Federal de Pelotas (UFPel), Pelotas, Brasil; rafaelhett@gmail.com (ORCID iD http://orcid.org/0000-0003-3361-2612).

3 Professor adjunto do Centro de Letras e Comunicação da Universidade Federal de Pelotas (UFPel), Pelotas, Brasil; Doutor em Letras; alfeu.sparemberger@outlook.com (ORCID iD http://orcid.org/0000-0001-6003-6353). 
works, by strongly rooted and historically constructed cultural elements. Differing from the vision normally attributed by occidentals that the Japanese society rigidity and its conventions are the very responsible for the mental individual's vulnerability, leading to the point of committing suicide, we see the necessity of amplifying the categories of comprehension concerning a culture extremely founded into ideals yet not well clarified for those who do not belong to it. We also believe that, maybe, literature can be the way of effectively doing this elucidation, since it cannot be isolated from the culture from which it comes.

KEYWORDS: Mishima Yukio, Patriotism, suicide, Japanese literature; cultural studies.

\section{Considerações iniciais}

O suicídio no Japão aparece com frequência na mídia ocidental, configurando-se como um tema particularmente instigante. É comum ouvir que na terra dos samurais há uma alta tendência à prática em razão da rígida organização social, culminando com um expressivo número de casos ligados a distúrbios psicológicos e, consequentemente, ao suicídio.

Uma pesquisa mais atenta, entretanto, mostra que essas associações não se sustentam. Segundo relatório publicado pela Organização Mundial da Saúde (OMS) em 2015, o índice de suicídios no Japão era de 15,4 para cada cem mil habitantes, isto é, o $26^{\circ}$ país no ranking. Nações como Suriname $(26,9)$, Cazaquistão $(27,5)$ e Mongólia $(28,1)$ aparecem na dianteira, atrás somente da Guiana $(30,6)$ e Sri Lanka, com o mais alto índice: 34,6 .

Sendo assim, por que logo o Japão foi escolhido como o principal alvo de comentários envolvendo a prática? Por que se propagou no ocidente a fama de um país de suicidas?

Ueno Kayoko, professora do Departamento de Sociologia da Universidade de Tokushima, debate a questão em seu artigo $O$ suicídio é o maior produto de exportação do Japão? Notas sobre a cultura do suicídio no Japão, pontuando: “A sociedade japonesa já há muito tempo fornece materiais únicos para estudos sociais sobre o suicídio" (UENO, 2005). Ela cita ainda o famoso 腹切 harakiri, forma invertida e considerada vulgar dos ideogramas 切腹 seppuku, antigo e honroso ritual de autoimolação permitido exclusivamente à classe samurai nos dias pré-Meiji. Menciona também o 心中shinjû, ou "suicídio duplo", palavra que caracteriza qualquer ato de suicídio feito por amor: da clássica relação impossível entre dois jovens até um pai que assiste toda a família morrer e se suicida em seguida. O shinjû tornou-se um tema muito apreciado na literatura e no teatro japonês, constituindo um gênero literário homônimo no qual o fim trágico das personagens é muito mais esperado e recorrente do que o típico "final feliz" dos enredos americanos e/ou europeus. Diante de tantas peculiaridades, a conclusão mais óbvia é a de que julgar o suicídio na sociedade japonesa valendo-se dos valores ocidentais é um ato genuinamente etnocêntrico. Supondo que a noção de suicídio não é concebida de modo idêntico por todos os 
grupos sociais, princípio elementar do Relativismo Cultural, as obras de escritores nipônicos possuem representações outras do suicídio? Se sim, de que forma essas representações podem, em uma análise mais ampla, dizer algo sobre o Japão no que concerne à prática?

Antonio Candido, no ensaio Literatura e a Vida Social, desenvolve a concepção de que a literatura enquanto arte é indissociável do meio em que é produzida. Ela, simultaneamente, sofre e gera influência em diferentes estratos sociais. Mais do que isso, serve de reforço aos valores vigentes, característica que independe do grau de consciência do artista ou dos receptores, mas é inerente à criação artística (CANDIDO, 1985, p. 2021). Isto posto, seria viável que a literatura servisse como instrumento de desnudamento do social, (re)exteriorizando elementos que possam fornecer dados sobre o tempo em que a obra foi concebida. À luz dos conceitos estudados pela antropóloga americana Ruth Benedict (1970) transpostos ao consagrado conto de Mishima, "Patriotismo", já revelam o intuito de situar o suicídio como um produto cultural fortemente enraizado e fundamentado em múltiplos fatores dessemelhantes a qualquer outro sistema social.

Escrito primeiramente em 1960 e publicado no Japão um ano depois, "Patriotismo" é dividido em cinco grandes atos de estilo icônico e poético, nos quais fica nítida a paixão de Mishima pelo teatro. A trama gira em torno do二 二六事件 Niniroku Jiken, uma tentativa de golpe de Estado ocorrida em 26 de fevereiro de 1936 (ano 11 da Era Shôwa). Movidos por uma ideologia de que o governo da época, aliado à elite, explorava as demais classes, instigava a pobreza e as tradições estrangeiras em detrimento das nacionais, além de esmaecer o verdadeiro poder do Imperador, os chamados jovens oficiais, inspirados pela Revolução Meiji, propunham a Restauração Shōwa. Em sua maioria oriundos da Academia do Exército Imperial Japonês (陸軍士官学校Rikugun Shikan Gakkô), eram tradicionalmente impedidos de ocupar posições no alto escalão, preenchidas por aqueles que frequentaram a Escola Militar Imperial (陸軍大学校Rikugun Daigakkô), de ensino superior e criada com o propósito de modernizar as Forças Imperiais do Japão segundo os moldes ocidentais.

Para entender de que forma esses complexos e rápidos eventos levam o protagonista da narrativa, Shinji Takeyama (武山信二), a se suicidar juntamente com sua esposa, é fundamental expor alguns conceitos que estão na base da sociedade japonesa e, portanto, constroem também o alicerce das personagens no que diz respeito a seus comportamentos e formas de tecer a realidade. Como Candido $(1985$, p. 36) já advertira, a força com a qual o meio cria padrões conformativos torna quase impossível ao indivíduo apresentar reações que fujam a essas normas, independentemente do domínio. Por conseguinte, estando o suicídio no horizonte social japonês por inúmeras razões e sendo o autor pertencente à sociedade, sua produção imprescindivelmente transporá a temática para o universo literário. 


\section{O conceito de hierarquia, on, gimu e giri}

Ruth Benedict, nos anos pós-Segunda Guerra Mundial, publicou uma complexa reflexão sobre o povo japonês na obra intitulada The Chrysanthemum and the Sword: Patterns of Japanese Culture (1970) e logo nas primeiras páginas já se vale do Relativismo Cultural quando declara:

We had to know the sanctions behind these actions and opinions. We had to put aside for the moment the premises on which we act as Americans and to keep ourselves as far as possible from leaping to the easy conclusion that what we would do in a given situation was what they would do. (BENEDICT, 1970, p. 5).

Na condição de antropóloga cultural, Benedict ressalta a conviç̧ão primeira de que um componente dentro de uma cultura nunca está isolado, mas faz parte de um sistema de relações passível de entendimento somente quando considerado em seu contexto original.

$\mathrm{Na}$ intenção de compreender a sociedade japonesa, Benedict apresenta o conceito de hierarquia. Segundo ela, "Japan's confidence in hierarchy is basic in her whole notion of man's relation to his fellow man and of man's relation to the State" (p. 43), isto é, a hierarquia é uma categoria básica de organização da realidade para os japoneses, assim como os conceitos de liberdade, igualdade e fraternidade são máximas para os países democráticos pós-Revolução Francesa. Na concepção japonesa de mundo, cada elemento possui um espaço adequado no esquema e qualquer desordem causará efeitos colaterais em outros segmentos do sistema. Inevitável é, porém, a discussão sobre a natureza da Antropologia como uma ciência generalizante das realidades que as analisa a fim de obter resultados palpáveis. Seria inconcebível querer computar todo o espectro de categorias organizacionais de todos os indivíduos de uma cultura. Em vista disso, faz-se necessário observar os fatores que se repetem e, por essa razão, saltam aos olhos do pesquisador. Mesmo que sempre abrangente e nunca estanque ou absoluto, a alta frequência de determinados aspectos culturais é suficiente para justificar seu estudo.

Assim, pode-se afirmar que a hierarquia para os nipônicos, ao contrário do que é popularmente exaltado, não está obrigatoriamente associada à rigidez. Aos olhos deles, a realidade é construída e organizada por meio de uma sociedade altamente hierarquizada em todos os pormenores da vida cotidiana, nas relações familiares e governamentais. Isso não significa que não haja aqueles que se sentem pressionados ou desconfortáveis com o código de conduta, pois, como já discutido, o espectro de análise é extenso e sempre englobará opiniões que o contradizem. Desde seus primeiros dias, contudo, uma criança no Japão aprende seu papel, primeiramente no interior do núcleo familiar e em seguida na macroesfera social. A escola cumpre o papel de reforçar e endossar os esquemas de poder, assim como outras instituições sociais, fazendo da hierarquia um aspecto realmente relevante no estilo de vida nipônico. 
Isso não ocorre ao acaso. A história do país possui fortes traços hierárquicos. Cerca de cem anos após o início do Período Kamakura (鎌倉時代, Kamakura jidai), sobe ao poder, em 1192, sob o título de shogun (将軍), Minamoto Yoritomo (源頼 朝), responsável por instaurar um sistema de governo constantemente comparado ao feudalismo europeu. Minamoto obteve êxito em deslocar a figura do Imperador para segundo plano e pôde governar sem a necessidade de derrubar a família real. Ademais, instaurou a sucessão do Shogunato mediante a hereditariedade, o que culminou em uma hierarquia já preestabelecida durante sete séculos, com muitas disputas de poder, mas na mão de, efetivamente, apenas três famílias com claras noções de seus papeis e atribuições naquele tipo de organização.

Embora o poder fosse relativamente centralizado, havia a figura dos senhores feudais, chamados então de 大名 daimyô. A fim de proteger suas propriedades, esses homens formaram exércitos de guerreiros, conhecidos como 侍 samurai, cuja lealdade era-lhes jurada por meio de uma série de acordos. Quando a família Tokugawa (徳 川家) assumiu o governo em 1603, marcas da hierarquia já presentes no shogunato Kamakura se acentuaram ainda mais. Tokugawa Ieyasu (徳川家康) promulgou inúmeras e detalhadas leis suntuárias sobre as permissões de cada classe nos domínios da vida pública e privada: das roupas e brinquedos até o tipo de moradia e alimentos a consumir. Cada família deveria pendurar em sua porta um indicativo da classe à qual pertencia, obedecendo a quatro categorias: samurais, agricultores, artesãos e mercadores. Obviamente, profissões vistas como tabu não eram sequer computadas nos censos, embora, à sombra da hierarquia organizadora do coletivo, nem de longe isso causasse revoltas do gênero que se conhece no Ocidente. Os Tokugawa obtiveram grande êxito em estabelecer uma ordem social centralizada muito estável, realçando o preceito japonês de "cada coisa em seu lugar". Foi nesse período também que o Japão expulsou a maior parte dos estrangeiros e decidiu fechar os portos para quase todas as economias mundiais, à exceção da Holanda (restrita ao território de Dejima, em Nagasaki) e da China. A essa política atribuiu-se o termo 鎖国 sakoku (país acorrentado).

Os fatos históricos citados são importantes para assimilar a profunda ligação da hierarquia com a sociedade japonesa, assim como a oportunidade de consolidação de ideais nacionais sem a interferência de referenciais oriundos de outros sistemas culturais. Não menos importante, a veneração da classe mais privilegiada dentro do Shogunato, os samurais, e das práticas somente a eles consentidas, é um ponto-chave. Posteriormente, voltar-se-á a esse tópico.

Em japonês, a palavra 恩 on significa, muito literalmente, favor, obrigação, débito, mas é utilizada em um sentido mais amplo do que os termos do mesmo campo lexical em português. Há diversos tipos de on recebidos por um indivíduo ao longo da vida, desde o 厚恩 kô on recebido do Imperador e do 親恩 oya on herdado dos pais, até o 主の恩 nushi no on recebido do senhor feudal. Esses débitos não podem ser recusados, são originados pelo simples fato de a pessoa existir e, portanto, devem ser pagos. 
Já a palavra 義務 gimu expressa que o pagamento desses débitos nunca será integral e não possuem tempo-limite, isto é, não poderão ser completamente quitados e perdurarão durante toda a vida do sujeito. Desse ponto de vista, continuar a linhagem familiar e educar os próprios filhos são parte do gimu chamado 孝 kô, a dívida para/com os parentes, ancestrais e dependentes. Ao contrário dos países de tradição greco-latina, no Japão não é habitual rememorar muitas gerações da árvore genealógica familiar, mas apenas os membros mais recentes. Consequentemente, há um deslocamento do pensamento japonês para a obrigação de um indivíduo com o presente e com o futuro somente, sem o sentimento de culpa e responsabilidade excessiva pelo passado. Já o 忠 chû refere-se à dívida com o Imperador, com a lei e com a nação, centrando na figura onipotente do Imperador a representação da união do povo. Sabiamente, desde o fim do Shogunato Tokugawa e do início do Período Meiji (明治時代 Meiji jidai), o Imperador continuou a não se envolver em decisões políticas, o que o isentaria de qualquer possível rejeição pública. É, de fato, muito raro que um cidadão japonês profira ofensas contra o Imperador. Além do mais, ele é visto como um descendente direto de 天照大 神 Amaterasu ooki kami (a Grande Deusa que os céus ilumina), e a quem eternamente se deverá o chü.

No círculo do 義理 giri, os débitos e seus pagamentos são vistos como suscetíveis de equivalência e possuem tempo-limite. Os giri-com-o-mundo, como nomeia Ruth Benedict, são os que ela descreve como contratuais. São obrigações mais impessoais, como aquelas com os familiares não tão próximos e com desconhecidos (e.g., a simples aceitação de um cigarro gera giri). Por sua vez, o giri-to-one s-name entra nos méritos deste artigo por estar diretamente relacionado a valores situacionais como reputação, honra, falha, desconhecimento e agressões.

Quando alguém é forçado pelo giri, os sensos de justiça e verdade podem parecer distorcidos para os ocidentais, contudo, na lógica japonesa tudo é válido para manter o equilíbrio do giri. Colateralmente, uma enorme pressão de conformidade com a opinião pública é gerada e muitos japoneses se queixam do quão pesado esse fardo pode se tornar. Ainda de acordo com Benedict:

Giri to one's name also requires that one live according to one's station in life. If a man fails in this giri he has no right to respect himself. This meant in Tokugawa times that he accepted as part of his self-respect the detailed sumptuary laws which regulated practically everything he wore or had or used (BENEDICT, 1970, p. 149).

É clara a invocação da hierarquia, uma vez que a violação da posição na pirâmide social culminaria em uma agressão direta às instâncias do giri e do on. Desobedecer às Leis Santuárias do período Edo (i.e., o governo dos Tokugawa, 1603-1868), por exemplo, era desrespeitar o chû consagrado ao criador desses regulamentos, o shogun 
(e não ao Imperador, nessa época). Ao ir contra seu dever, o transgressor mancharia seu nome e sua reputação, às vezes até o de seus descendentes e, mais raramente, de seus ancestrais. Logo, deveria encontrar uma maneira de purificar sua mácula.

Ueno Kayoko comenta, baseada nas observações de Benedict, as formas de redenção e suas origens: “(...) os japoneses, que não têm nem uma bússola interior forte nem o sentimento cristão da culpa, estão fortemente inclinados a salvar seu nome, ou mesmo a fama da nação, através do suicídio" (UENO, 2005). Por ter sido um país fortemente influenciado pelo Budismo, o qual prega a morte como transcendência, o Japão sempre ponderou o suicídio tão somente como uma alternativa entre várias outras, inclusive, a mais heroica e digna em muitas ocasiões. Segundo a doutrina budista, a essência permanece mesmo que o exterior mude. Na prática, isso significa que um espírito guerreiro continuará a sê-lo, independentemente do número de reencarnações. Assim sendo, o pânico da morte e, mais especificamente do fim que a morte possivelmente acarreta, estava ausente no imaginário japonês mais tradicional, ainda não influenciado pelo Cristianismo. O suicida não estava necessariamente desesperado ou mentalmente doente, como se crê no ocidente, mas, pelo contrário, sua morte era capaz de restaurar o equilíbrio do on e o primor de sua alma e de sua memória sem maiores consequências no grande plano existencial, do qual o terreno nada mais é do que uma efemeridade trivial.

Historicamente, constata-se que o símbolo do suicídio foi constantemente (re) ativado em momentos mais recentes:

O Japão fazia propaganda do suicídio, de certa forma encorajando seus membros a cometer atos suicidas, ao implantar vocabulários relacionados ao salvamento da fama, para impedir uma possível rebelião contra o governo. A figura do Kamikaze foi idealizada para glorificar a guerra. É importante lembrarmos que, antes de a Toyota, a Mitsubishi, e outras companhias japonesas serem criadas e transformadas em representantes do poderio e capacidade japoneses, entre outros fenômenos que atestavam a nossa "macheza" estava a nossa capacidade de cometer o suicídio. Assim, o suicida funcionava como uma "bala humana" usada contra o inimigo, não somente metaforicamente, mas no sentido literal da palavra. Assim também funciona a resistência no Iraque e em Israel. Onde quer que exista escassez de armas, ou de outros produtos manufaturados para exportar, os recursos humanos se tornam no substituto ideal (UENO, 2005).

Benedict também cita uma gama de circunstâncias durante a Segunda Guerra em que o próprio governo encorajava o suicídio: no campo de batalha, por exemplo, um soldado deveria lutar até a morte (só assim estaria pagando o chû) e de forma alguma deveria se render. Caso a captura fosse iminente, o suicídio não era uma escolha, mas um imperativo. 


\section{O tempo de Yukio Mishima e o amor pela morte}

Mishima Yukio (三島由紀夫), pseudônimo de Hiraoka Kimitake (平岡公威), certamente é um dos autores mais enigmáticos da literatura japonesa contemporânea. Nascido em 14 de janeiro de 1925 (ano 14 da Era Taishô) no seio de uma família samurai, foi criado em Tóquio sob uma atmosfera política e econômica extremamente ambígua, mas que, sem dúvidas, fortaleceu em sua mente a imagem de um Japão imperial pleno e poderoso, embora em poucos anos todo esse esplendor tenha sido encoberto pelas cinzas da Segunda Guerra Mundial.

$\mathrm{O}$ ano de nascimento de Mishima marca a transição entre a Era Taishô (大正時代 Taishō jidai, era da grande integridade, 1912-1926) e a Era Shôwa (昭和時代 Shōwa jidai, era de luz e harmonia, 1926-1989), os dois primeiros governos após a gloriosa Restauração Meiji (明治維新, Meiji ishin). Foi durante a Era Taishô que o Japão se tornou uma grande potência asiática e conquistou o reconhecimento das principais nações ocidentais, unindo-se aos Aliados na Primeira Guerra Mundial para se apoderar de diversos territórios de influência alemã na China, além de partes da Sibéria quando a Revolução Bolchevique desestabilizou o regime czarista russo.

Logo após, o Japão ganhou um assento permanente no Conselho da recémfundada Liga das Nações e se tornou uma das cinco grandes potências do novo mundo pós-guerra. Apesar disso, havia um grande descontentamento político e econômico por parte da população civil, que lutava pelo sufrágio universal masculino (até então determinado por um fator de renda mínima) e por uma reforma do sistema político japonês a fim de permitir a ampliação do eleitorado. Sendo tais mudanças nitidamente desagradáveis à aristocracia vigente, foram promulgadas, com o propósito de manter a integridade das instituições nacionais e protegê-las do socialismo crescente, as Leis de Preservação da Paz. Ainda assim, os membros da Dieta ${ }^{4}$ dificilmente conseguiam conciliar seus interesses e à Crise de 1929, bem como a Segunda Guerra Mundial, somaram-se no processo que deu início ao declínio do Japão em múltiplos setores.

É nesse cenário que Mishima assistiu, já no Período Shōwa, a um crescimento do ultranacionalismo, do totalitarismo e do fortalecimento militar. Em especial nos anos que sucederam a rendição do Japão em setembro de 1945, o país polarizou-se entre os que eram a favor e os que eram contra a intervenção ocidental.

No geral, em respeito ao chu evocado no discurso imperial ${ }^{5}$ de cessar fogo e agir honrosamente perante o mundo, os japoneses reagiram com simpatia à ocupação estadunidense. Era frequente presenciar famílias acenando para o exército americano e

4 Órgão do Poder Legislativo, em japonês chamado de 国会 kokkai. Primeiramente constituído em 1889, teve a forma de funcionamento alterada em 1947. É formado da Câmara dos Conselheiros (alta) e Câmara dos Representantes (baixa). Dentre as funções mais importantes da Dieta está a escolha do primeiro-ministro.

5 Conhecido como 玉音放送 Gyokuon-hōsô, foi proferido pelo Imperador Hirohito em 15 de agosto de 1945. Nele, o Imperador diz aceitar a Declaração de Potsdam, que exigia a expressa rendição japonesa. 
tanto a população quanto o governo militar e civil (relativamente autônomos no Japão da época) não fizeram objeções às modificações radicais impostas pelo lado vencedor (BENEDICT, 1970, p. 172). Não era o caso de Mishima. Contra a política ocidental, ele partilhava de um sentimento de desconforto, de traição e de angústia. Apesar disso, tinha divergências com os nacionalistas por culpar o imperador pela derrota na guerra e defender sua abdicação.

$\mathrm{Na}$ vida pessoal, desde cedo foi proibido pelo pai de escrever. Acabou por se graduar em Direito pela Universidade de Tóquio, ocupando uma posição promissora no Ministério das Finanças. A paixão indômita pela literatura, no entanto, abrandou a rigidez paterna, possibilitando que ele adotasse integralmente a carreira de escritor. Halterofilista, praticante de caratê e faixa preta de quinto grau no Kendo, Mishima cultuou seu corpo como um santuário e exibiu-o em diversas fotos nas quais aparece quase nu, com os músculos saltados em contraste com a reluzente espada samurai. Atuou ainda como cineasta, ator, crítico, falava fluentemente francês e inglês e era leitor assíduo de obras literárias europeias clássicas.

Sua produção é permeada de temáticas ligadas à morte, à sexualidade, às tradições e às mudanças sociais da época. Paulo Leminski, no posfácio de uma das últimas obras do autor, Sol e Aço (1968), diz:

Em Mishima, realiza-se, em carne viva, o drama essencial da intersubjetividade, no qual olhar é um ato agressivo de apropriação do objeto pela consciência de outro, no qual "ser olhado" é sinônimo de "estar morto". No pleno exercício do existir, as pessoas são invisíveis. Só a morte lhes dá a opaca presença absoluta de um objeto de mundo, de uma obra de arte, por exemplo (p. 111, 1968, grifo do autor).

Categoricamente, o suicídio era recorrente nos textos de Mishima. Sobre esse tópico Leminski observa: “A autoimolação, para ele, era uma obra de arte, algo a ser preparado, saboreado por antecipação, a chave de ouro de uma vida, um clímax" (p. 115). Os personagens de suas histórias normalmente desenvolvem algum tipo de isolamento e de desespero pessoal, e a morte, frequentemente na forma de suicídio, aparece como meio ideal de transcender e de encerrar um ciclo imperfeito e improdutivo.

Ainda sobre a poética de Mishima, é válido o pensamento de Antonio Candido ao considerar que

(...) a primeira tarefa é investigar as influências concretas exercidas pelos fatores socioculturais. É difícil discriminá-los, na sua quantidade e variedade, mas podese dizer que os mais decisivos se ligam à estrutura social, aos valores e ideologias, às técnicas de comunicação. $\mathrm{O}$ grau e a maneira por que influem estes três grupos de fatores variam, conforme o aspecto considerado no processo artístico. (...) Eles 
marcam, em todo caso, os quatro momentos da produção, pois: a) o artista, sob impulso de uma necessidade interior, orienta-o segundo os padrões da sua época,

b) escolhe certos temas, c) usa certas formas e d) a síntese resultante age sobre o meio (CANDIDO, 1985, p. 21).

Nesse trecho, Candido não só destaca a importância vital da esfera sociocultural no desenvolvimento da produção artística, como também interliga o criador e sua individualidade ao mundo exterior, considerando todos os aspectos inseparáveis do produto final e de sua repercussão. Assim, ao abordar o suicídio em seus escritos, Mishima incorporou visões do sistema cultural no qual estava inserido, perspectivas acentuadas por sua proximidade e devoção ao Código Samurai.

\section{O seppuku dentro do código samurai}

A despeito dos samurais gozarem de inúmeros privilégios, o on cobrado era consideravelmente maior, por mais que nenhuma das demais classes fosse isenta dele. A intensa cobrança social fez surgir o武士道 Bushidô, o rígido Código Samurai baseado em ideais de honra, lealdade, autocontrole, bravura e inúmeros outros valores considerados nobres e dignos de uma casta guerreira. Em qualquer condição na qual o Código fosse quebrado, a situação se tornasse incontornável ou sob ordens expressas de seu daimyô, o samurai deveria cometer seppuku para proteger seu nome e glória. $\mathrm{Na}$ forma de um complexo e cerimonioso ritual, o guerreiro abria o ventre com a própria espada a fim de mostrar que o interior ainda se preservava imaculado. A fim de evitar o sofrimento e um possível fraquejo, um ajudante chamado介錯人 kaishakunin era responsável pelo golpe de misericórdia: a decapitação. A simbologia do seppuku envolvia, por meio de um ato altamente doloroso, a manutenção do autocontrole, da resistência e da força de um samurai até mesmo nos instantes finais. Não raramente contava com espectadores, que asseguravam a correta execução do ato para que não se pusesse em dúvida a honra do morto.

Por mais que o seppuku fosse um privilégio dos samurais, estes serviam de modelo para os demais indivíduos situados mais abaixo na hierarquia, como é típico em organizações assimétricas que elegem o que será desejado e cobiçado. De modo algum isso explica por si só a complexidade do fenômeno aqui discutido, posto que, como já mencionado, o giri, a Filosofia budista, a organização social e a história do Japão são fundamentais para a elucidação dos fatos. Ainda assim, os ensinamentos do Bushidô e a figura do guerreiro que pode morrer a qualquer momento em nome de sua honra não podem ser desvinculados como determinantes na construção coletiva da visão de como e por que alguém comete suicídio, sem uma conotação obrigatoriamente negativa. 


\section{5. "Patriotismo" (1960) para além do texto}

Em 1960, Yukio Mishima publica o que para alguns críticos literários é sua obraprima do gênero conto. Intitulada originalmente 憂国 yûkoku, a priori é pertinente analisar os ideogramas que compõem o título. Estão presentes os kanji de "preocupação, melancolia" (憂) e o de "país, nação" (国). Traduções ocidentais optaram pelo termo "patriotismo", porém é apropriado questionar se tal definição é capaz de abarcar a totalidade semântica desse vocábulo dentro da cultura japonesa.

O dicionário on-line Michaelis define patriotismo como "Amor à pátria, devoção ao seu solo e às suas tradições, à sua defesa e integridade", noção que parece limitada para o sentido de yûkoku, dado o primeiro ideograma que a compõe. Seu sentido ultrapassa o mero amor pela pátria e o simples apreço pela tradição para significar uma real inquietação sobre o futuro, uma incerteza que atinge desde as esferas mais externas e sociais do ser até as mais subjetivas.

Um estudo do fato histórico que inspirou Mishima na criação do conto pode fornecer pistas para a interpretação do título. Denominado 二 ・ 二六事件 $\mathrm{Ni} \mathrm{Ni}$ Roku Jiken, teve início na noite de 26 de fevereiro quando insurgentes foram bem-sucedidos no assassinato de vários dos principais conselheiros próximos ao Trono, embora tenham falhado em tomar o controle do Palácio Imperial. Ao tomar ciência dos acontecimentos e ser aconselhado a não ceder, o Imperador Hirohito solicitou - sem especificar de que maneira - a Kawashima Yoshiyuki (川島 義之) e Honjô Shigeru (本庄繁), na época Ministro da Guerra e Ajudante de Campo respectivamente, que contivessem a revolta, recusando, todavia, a proposta de Kawashima de formar um gabinete que clarificasse a política Imperador-Estado (国体 kokutai) e fortalecesse a vida e a defesa nacionais.

Após três dias de falhas sucessivas, Hirohito ameaçou ele mesmo assumir o comando das tropas imperiais, expedindo a pedido de Sugiyama Hajime (杉山元), vice-comandante das Forças Armadas, um Comando Imperial permitindo o uso de força no controle dos rebeldes. Tendo o imperador ignorado todas as solicitações por parte dos revoltosos, estes foram cercados na manhã do dia 29 por mais de 20 mil soldados. Mensagens aconselhando a não resistência às forças imperiais foram lançadas por aviões oficiais, amparando-se na força do $c h \bar{u}$ contido no Comando Imperial. Ao anoitecer, todas as tropas insurgentes haviam se rendido, dois líderes haviam cometido suicídio e os demais foram presos pela polícia.

Assim, "Patriotismo" é dividido em cinco atos, com o primeiro já informando sobre a morte do casal e alterando o foco para o que se passou nos momentos que antecedem o shinjū, uma interessante técnica narrativa operante na constituição de um grande flashback cujo único e privilegiado espectador é o leitor. Tem-se então acesso à intimidade do protagonista Takeyama Shinji (武山信二) e de sua mulher, Reiko (麗子), durante os três dias que compreendem o episódio. Tenente do Batalhão de Transporte Konoe, Takeyama é profundamente afetado pelos acontecimentos do Ni Ni Roku Jiken, uma vez que deverá empunhar sua espada contra seus companheiros insurgentes, os 
quais, por respeito ao seu recente e próspero casamento, mantiveram-no à parte do planejamento. Impedido de decidir entre cumprir com seu dever de militar e quitar sua dívida com os colegas, opta por cometer seppuku na noite de 28 de fevereiro. É acompanhado por sua jovem esposa, que se suicida cravando uma adaga no pescoço.

Fundamentalmente, a narrativa pode ser definida por uma desarmonia entre diferentes tipos de on: o chû, para/com o Imperador, o Japão e a lei; o 任務 ninmu, para/com as obrigações do trabalho e o giri-para-o-mundo, mais especificamente para/ com os colegas insurgentes devido ao ato de respeito e consideração por eles prestado. O conflito da obra, ilustrado pela fala "- Amanhã deverão mandar tropas imperiais. Acho que eles serão considerados rebeldes. Vou comandar uma unidade para atacá-los... Não posso fazer isso. É impossível fazer uma coisa dessas." (p. 109, grifo meu) põe em xeque a estabilidade do giri-to-one's-name, pois matar aqueles que outrora foram tão atenciosos poderia ser visto como uma atitude desonrosa e de desprezo. O suicídio vem então como forma de restabelecer esse equilíbrio e preservar a integridade de todas as partes, ao menos na visão do protagonista. O suicídio de Reiko evoca seu giri-para-omundo, aqui subentendido por sua condição de esposa e sua responsabilidade para/com o marido e para/com a estrutura familiar.

O suicídio funciona em "Patriotismo" como elemento de catarse, a linha que costura todos os fatos e dá sentido ao que é narrado. Para o objeto deste artigo, são significativas as passagens do terceiro, quarto e quinto atos, embora no momento o foco detenha-se unicamente no terceiro. A partir dele (em "Embora a casa do Encarregado do Selo Privado, Saito, ficasse no mesmo bairro, nenhum dos dois ouviu o tiroteio, na manhã de 26 de fevereiro", p. 106), a morte é evocada explicita e repetidamente, manipulando o tom da narrativa. Consequentemente, é nesse ato que Reiko e Shinji decidem se suicidar, como é sugerido em dois excertos:

No rosto do tenente, quando saiu apressado em meio à neve da manhã, Reiko vira a determinação de morrer. Se o marido não voltasse, sua decisão estaria feita: morreria também (MISHIMA, 1987, p. 106).

Compreendeu perfeitamente que o marido falava da própria morte. O tenente estava resolvido. Cada palavra, com raízes na ideia da morte, brotava bem definida e com intenso significado contra o fundo escuro e imóvel (1987, p. 109).

No início do terceiro ato, o foco narrativo recai sobre Reiko, e descreve a morte simultaneamente enquanto destruição e luz: "Estava feliz e preparada para a viagem a caminho da destruição, naquela cintilante carruagem do sol" (p. 107). Mais do que isso, ela não vê a morte com temor, mas acolhe-a com alegria, como uma maneira de se conectar ao marido: 
Não sentia medo da morte que pairava sobre ela. Esperando sozinha em casa, Reiko acreditava piamente que tanto os sentimentos do marido naquele instante, sua angústia e abatimento - quanto a força da sua carne - a levavam a acolher a morte com alegria. Era como se seu corpo pudesse se derreter facilmente para se transformar na mínima fração dos pensamentos do marido (1987, p. 107).

Quando especificamente o suicídio é posto em discussão nos diálogos diretos das personagens, chama a atenção a extrema banalidade, simplicidade e objetividade pela qual o ato de se matar é tratado: “_ Muito bem, então... (...) Esta noite vou abrir minha barriga" (Shinji a Reiko, p. 109). Em seguida, Reiko pede permissão para acompanhar o esposo, ao mesmo tempo em que ambos sentem o "coração transbordando de felicidade" (p. 110). Imediatamente ela informa em tom rotineiro que a água está quente e pergunta se ele gostaria de tomar banho e jantar, naturalidade que chega a surpreender o próprio tenente: "As palavras foram ditas em tom tão normal e doméstico que o tenente por um momento chegou a pensar que tudo não passava de alucinação" (p. 110, grifo meu). Após tomarem saquê e irem se deitar, a reflexão de Takeyama conclui que a decisão de se matar não afetara em nada a rotina do casal, reforçando a trivialidade do que estava por vir: "Até mesmo o momento em que se deitava à espera da mulher não era mais cedo e nem mais tarde do que de costume" (p. 113).

Na visão de Shinji, a morte é concebida como parte de um ritual muito estrito e, por consequinte, merece uma atenção especial: "Aproximando o rosto do espelho escuro, partido e embaçado, o tenente barbeava-se com todo o cuidado. Essa seria sua máscara de morte. Não devia ter nenhuma imperfeição desagradável" (p. 112, grifo meu). A partir da clara referência ao teatro 能 $N \hat{\text { e }}$ às máscaras nele utilizadas, é possível a inferência de que a morte é concebida mediante uma estética minuciosa na busca de uma suposta perfeição. Em outras obras de Mishima, a referência à morte fortemente caracterizada pela beleza e pela perfeição, um ato ritualístico e segmentado em etapas meticulosas, não é incomum, e, inclusive, é explicitamente descrita desse modo.

Como era típico do seppuku, uma testemunha deveria assegurar que tudo ocorresse de acordo com a tradição para que não surgissem infâmias. É por isso que Shinji pede à esposa: "— Ótimo, partiremos juntos. Mas quero que, antes, seja testemunha do meu suicídio" (p. 109). Imediatamente, é explicado pelo narrador: "Para o tenente era essencial que, não importa o que acontecesse, sua morte não apresentasse nenhuma irregularidade. Para isso precisava de uma testemunha" (p. 110).

Ademais, o ato três apresenta o suicídio associado à liberdade de espírito e ao prazer carnal. Durante uma intensa cena de relação sexual, aparecem passagens como: "Com as línguas explorando, alcançando o interior macio e úmido das suas bocas, era como se as agonias ainda desconhecidas da morte tivessem temperado seus sentidos com a sensibilidade do aço em brasa. Agonias que não sentiam ainda, as distantes dores da morte haviam refinado sua sensação de prazer" (p. 115, grifo meu); “(...) tudo se 
incendiava com a consciência de que aquela era a última vez” (p. 114); “(...) a verdade era que o tenente nunca antes experimentara uma liberdade tão completa" (p. 113).

Enfim, é possível marcar um pertinente contraste entre imperfeição e perfeição, sagrado e corrompido, ardor e frieza, juventude do sujeito e senilidade social, no trecho em que Shinji reflete sobre a sociedade japonesa e, ao fim do ato, nos fragmentos sobre os corpos do casal:

A buzina ecoou nas paredes mais próximas... Escutando, teve a impressão de que a casa erguia-se em uma ilha solitária no oceano de uma sociedade que prosseguia incansável como sempre na sua atividade de todos os dias. À sua volta, vasta e desordenada, estendia-se a terra pela qual ele chorava. Ia dar a vida por ela. Mas o grande país, pelo qual estava disposto a se destruir, daria atenção à sua morte? Não sabia, e não fazia diferença. Seu campo de batalha era sem glória, um campo onde ninguém poderia realizar façanhas valorosas, a linha de frente do espírito (p. 114 , grifo meu).

A calma tranquila da testa alta, os olhos fechados com os cílios longos sob as sobrancelhas suavemente desenhadas, a forma perfeita do nariz, o brilho dos dentes entrevistos entre os lábios cheios e bem-feitos, as faces macias e o queixo pequeno e sensato... tudo isso formou na mente dele a visão de uma máscara de morte realmente radiante (...) (sobre Reiko, p. 115, grifo meu).

Um odor doce e melancólico emanava das axilas escondidas pela abundância de músculos do tórax e dos ombros, e na doçura desse cheiro estava contida, de alguma forma, a essência da morte jovem (sobre Shinji, p. 117, grifo meu).

Seus corpos, úmidos de suor, apertavam-se um contra o outro, e cada centímetro das duas formas jovens e belas formavam um todo tão uniforme que parecia impossível qualquer separação (sobre ambos, idem, grifo meu).

Embora ainda parcialmente analisado, tais fragmentos já permitem entrever que a representação do suicídio dentro do conto de Mishima abre-se para significados outros além da costumeira atribuição da psicologia ocidental às disfunções mentais. Da maneira análoga, uma análise mais profunda da obra do escritor e de outros que se inspiraram na temática pode fornecer subsídios para desconstruir as visões engendradas da autoflagelação japonesa, que a recusam enquanto símbolo culturalmente estabelecido.

\section{Considerações finais}

Mishima Yukio, por meio de sua sensibilidade ímpar e pensamentos avant-garde, foi um dos grandes autores que canalizaram o elemento do suicídio para dentro de sua obra na forma de símbolos com significados diferentes do habitual para leitores de outros sistemas culturais, originando importantes reflexões e materiais de discussão. 
Em "Patriotismo", a começar pelos ideogramas que compõem o título original, representativos de um debate envolvendo as imposições dos Estados Unidos no pósSegunda Guerra (que visavam transformar o Japão em uma "boa nação", mas segundo os ideais morais estadunidenses), e a falha do Ni Ni Roku Jiken (acarretando um avanço do militarismo na esfera civil) são fatores — não os únicos — muito justificáveis para a aplicação da ideia de preocupação com o futuro, presente na palavra yûkoku. Mais do que isso, todos esses componentes funcionam com papéis bem específicos na criação de um enredo impetuoso, recoberto de mistério, fragmentado e ao mesmo tempo costurado pela ideologia suicida, amparada por um sentimento nacionalista e de dever a cumprir.

Um caso tão particular como o do Japão, em que a presença do on, de uma organização social pautada na hierarquia, somada a uma história ímpar com a duradoura presença de uma classe guerreira erigida sob ideais de honra e integridade, e cingida por uma ideologia budista, dota esse pressuposto de uma força sem igual. Mishima prova sua relevância e atemporalidade dessa maneira, codificando as complexidades de seu mundo e de seu tempo em seus escritos, razão pela qual a literatura pode ser a conexão entre esses mundos, da ficção às reais particularidades da Terra do Sol Nascente.

\section{Referências Bibliográficas}

BENEDICT, Ruth. The Chrysanthemum and the Sword: Patterns of Japanese Culture. $23^{\mathrm{a}}$ reimpressão. Tóquio: First Tuttle, 1970.

CANDIDO, Antônio. Literatura e Sociedade: estudos de teoria e história literária. $7^{\mathrm{a}}$ ed. São Paulo: Editora Nacional, 1985.

MISHIMA, Yukio. Morte em pleno verão e outras histórias. Rio de Janeiro: Rocco, 1987.

Sol e aço. Tradução e posfácio por Paulo Leminski. $1^{a}$ edição. São Paulo: Editora Brasiliense, 1985.

NITOBÉ, Inazo. Bushido: the soul of Japan. Chapel Hill: The Project Gutenberg: Chapel, 2004. Disponível em: <http://www.gutenberg.org/files/12096/12096-h/12096-h.htm>. Acesso em: 17 fev. 2017.

PATRIOTISMO. In: DICIONÁRIO On-line Michaelis. São Paulo: Editora Melhoramentos. 2015. Disponível em: $<$ http://michaelis.uol.com.br/busca? $\mathrm{r}=0 \& \mathrm{f}=0 \& \mathrm{t}=0 \&$ palavra $=$ patriotismo $>$. Acesso em: 12 fev. 2017.

SAKAMOTO, Paulo. Ouça o áudio original do discurso de rendição do Imperador Showa. Disponível em: <http://www.ipcdigital.com/nacional/ouca-o-audio-original-do-discursode-rendicao-do-imperador-showa/> . Acesso em: 29 jun. 2017.

UENO, Kayoko. "O suicídio é o maior produto de exportação do Japão? Notas sobre a cultura de suicídio no Japão". Revista Espaço Acadêmico, no 44, janeiro, 2005. Disponível em: $<$ https://www.espacoacademico.com.br/044/44eueno.htm>. Acesso em: 26 jan. 2017. 